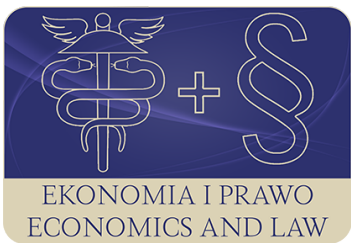

EKONOMIA I PRAWO. ECONOMICS AND LAW

Volume 18, Issue 3, September 2019

p-ISSN 1898-2255, e-ISSN 2392-1625

www.economicsandlaw.pl

EKONOMIA I PRAWO
ECONOMICS AND LAW

ORIGINAL ARTICLE

received 26.03.2019; revised 12.07.2019; accepted 30.09.2019

Citation: Kościółek, S. (2019). Do sports clubs differ from other non-governmental organizations in terms of revenue sources? The case of Poland. Ekonomia i Prawo. Economics and Law, 18(3): 283-294. doi:10.12775/EiP.2019.020.

\title{
Do sports clubs differ from other non- governmental organizations in terms of revenue sources? The case of Poland
}

\author{
SZCZEPAN KOŚCIÓŁEK \\ Jagiellonian University in Cracow, Faculty of Management and Social Communication, \\ Institute of Entrepreneurship, ul. prof. S. Łojasiewicza 4, 30-348 Kraków, Poland \\ ๑ szczepan.kosciolek@uj.edu.pl \\ (iD) orcid.org/0000-0001-7705-4216
}

\begin{abstract}
Motivation: Although some authors have claimed that sports clubs generate revenues from more different sources than do other non-profit organizations, relevant research is lacking.

Aim: To fill this gap, this paper compares sports clubs with other non-profit organizations in terms of the (1) revenue structure and (2) revenue sources. The analysis used data from the financial reports of all public benefit organizations (PBOs) registered in 2015, thereby covering the whole population. Thus, exploratory methods were used to compare 679 sports clubs having $\mathrm{PBO}$ status with other 6816 registered PBOs.

Results: A greater share of sports clubs (SCs) than other PBOs exploits public funding, particularly subsidies from local self-governments. SCs also rely on membership fees and other revenues (such as business activities and sponsorship) more than do other organizations. These results contribute to the knowledge of financial specificity of non-profit sports clubs and show which revenue sources could be used by clubs to a greater extent.
\end{abstract}

Keywords: non-profit organizations; public benefit organization; revenue structure; sports clubs JEL: L31; L83; Z23

\section{Introduction}

One of the three providers of mass sports alongside commercial initiatives and public activity, non-profit sports clubs play a key role in modern sports. 
They create space for sports competitions, popularize mass sports, and support social networking (Nagel, 2008, pp. 121-141). Non-profit sports clubs differ from for-profit ones in the purposes of their activities (social versus business), funding sources (public versus private), and main forms of employment and remuneration (voluntary work combined with civil law contracts versus full-time and contractual systems) (Cieśliński \& Perechuda, 2015, pp. 2185-2189).

In general, non-profit organizations (NGOs) differ in their level of revenue diversification, which also largely depends on their type of activity (Fischer et al., 2011, pp. 662-681). Furthermore, the fact of offering public or private services and the mission of the organization affect the type and structure income of NGOs (Achleitner et al., 2014, pp. 85-99; Kearns, 2007, pp. 291-314). Among them, sports clubs have great deficiencies in basic resources, such as human resources, financial capabilities, networks, and infrastructure (Gumulka et al., 2005, pp. 12-15; Wicker \& Breuer, 2011, pp. 188-201). Coates et al. (2014, pp. 230-248) explain that potential financial problems strongly depend on the ways in which a sports club obtains financial resources: The higher the share of sponsoring is in the revenue structure, the lower are the public subsidies and the greater the financial problems can be. In addition, the increasing share of public funding in the revenue structure increases the dependence of the clubs' activities on the directions assigned to them by the government or local self-government (Sotiriadou \& Wicker, 2013, pp. 297-314; Wicker et al., 2015, pp. 5-24). On the other hand, this is public funding that is considered a key element of the revenue structure of sports organizations, enabling them to improve their financial and organizational situations (Caslavova \& Berka, 2005, pp. 204-213; Lasby \& Sperling, 2007, p. 47). From these results, it follows that the functioning of sports clubs depends on the choice of revenue sources.

Some authors claim sports clubs have problems to maintain financial viability (Cordery et al., 2013, pp. 186-199; Wicker et al., 2015, pp. 5-24), and that sports clubs diversify the structure of their revenues as a result of many internal and external factors, such as organizational mission, level of budget, size of the club, the percentage of women and so on (Barget \& Chavinier-Rela, 2017, pp. 7-34; Wicker et al., 2013, pp. 119-136).

However, the issue of comparing revenue structures of sports clubs with that of other NGOs seems to be disregarded in the literature. To fill this gap, this research aims to study how sports clubs differ from other non-profit organizations in terms of (1) revenue structure and (2) revenue sources. Revenue structure is determined by the proportions of the revenue generated by each source in the organization's total revenue. The use level of a particular revenue source can be determined by the number of organizations that use this source. To fulfill these aims, the present research will compare financial reports of sports clubs and other public benefit organizations (PBOs).

According to the data of the Central Statistical Office (2017, p. 22), at the end of 2016 there were nearly 15000 sports clubs in Poland. Furthermore, 
this number has been growing steadily since 1989. After fulfilling certain formal requirements, sports clubs (as the non-profit organizations) may apply for the status of a public benefit organization. Such a status gives them a number of additional organizational and financial possibilities (Act on Public Good Activity and Volunteering, 2003, article 24, paragraph 1-2 and article 27, paragraph 2). A PBO is allowed to receive donations of $1 \%$ of personal income tax, can use state and local self-government properties on preferential terms, and is provided with a number of tax exemptions (Act on Public Good Activity and Volunteering, 2003, article 24, paragraph 1-2 and article 27, paragraph 2). Each $P B O$ must submit an annual financial report, and this research uses all reports PBOs submitted in 2015.

Moreover, any club can be associated in a sports association (Act of Sport, 2010, article 2, paragraph 2). Being members of such an association, sports clubs - as is typical of the European sports market - compete with each other in league competitions organized by this association. This creates a certain discrepancy between the statutory objectives (i.e., the popularization of sports and physical culture) and a potential club policy to improve purely sporting performance. This discrepancy can be especially serious in Poland, because Polish non-profit sports clubs pay much more attention to competition and sporting performance than do their counterparts in other European countries (Breuer et al., 2017). Therefore, only these kinds of sport clubs were included in the analysis.

\section{Materials and methods}

The data about the studied entities come from the PBOs' annual financial reports for 2015, downloaded from the database of the Ministry of Family, Labor and Social Policy of Poland (2018). Each PBO has to submit such a report every year. The report form divides revenue sources into (1) unpaid activities, (2) paid activities, (3) business activities, and (4) other activities (table 1). In addition to these data, the Ministry database includes information on the organizations' assets; the revenue due to donations of $1 \%$ of personal income tax; scope of activities; the number of members, employees, volunteers; and the descriptions of initiatives.

PBOs can also be classified by the form of ownership of funds received. In their reports, organizations specify which revenues come from private sources (e.g., membership fees, donations, public generosity, non-financial income), public sources (e.g., subsidies and donations of $1 \%$ of personal income tax), and others (including business activities). More detailed than that in table 1 , this classification is used in financial reports of large organizations, that is, those with annual revenues of over 100000 PLN. Thus, the analysis of revenue sources divided by type of activity (table 1) applies to all sports clubs, while this more detailed analysis applies only to large ones. Table 2 and chart 1 show both analyses, the one for large organizations being presented in the second part of the table 2. and, respectively, right side of the chart 1. In 2015, out of 679 
sports clubs with the PBO status, 365 were large; out of 6816 other PBOs, 3 879 were large. As mentioned above, however, these clubs constitute only a part of the non-profit sector of sports organizations: At the end of 2016, there were nearly 15000 sports clubs in Poland (Central Statistical Office, 2017, p. 22).

In the analyses, we treat revenues due to donations of $1 \%$ of personal income tax as public sources, to make it possible to compare the results with those for countries which do not have such a form of tax allowance.

We will analyze the data in two steps. First, based on their statutory activities declared in the reports, we will separate PBOs which declared activities for disseminating physical culture and sports from other PBOs. We will then compare revenue sources of these two groups. Since we can analyze the whole population of $\mathrm{PBOs}$, we will analyze the data with summary statistics, including mean, standard deviation, coefficient of variation (CV), median, skewness, and maximum value.

\section{Results}

For both sports clubs and other PBOs, the most frequent revenue source was unpaid activities, and, for large sports clubs, also private revenue sources (chart 1). While a greater share of sports clubs than that of other PBOs used business activities to generate revenues, a smaller share of clubs used paid and other activities. Similar shares of sports clubs and other PBOs (over 90\%) used private and other sources. A greater share of sports clubs, however, received more public support than that of other PBOs (92\% against 78\%). The difference was due to local government subsidies (received by $86 \%$ of clubs and only $64 \%$ of other PBOs) and membership fees (used by $79 \%$ of clubs and $57 \%$ of other PBOs). Other revenue sources, excluding rare legacies and property income, were less frequent in sports clubs than in other PBOs.

The revenue structure of all PBOs, including clubs, was based mainly on unpaid activities (table 2). On average, this source had a greater share in the revenues of other PBOs whereas business and other activities had greater shares in the revenues of sports clubs. Considering individual sources, local self-government subsidies showed the greatest disproportion between the two groups. In addition, sports clubs generated relatively more revenues from membership fees and other sources than did other PBOs.

Coefficient of variation confirmed a great diversity of both populations in terms of shares of the analyzed sources in total revenues. For most sources, median share was close to $0 \%$ (which means that at least half of the organizations generated no revenue from such a source); some PBOs had just one revenue source (for such an organization, a maximum share reached $100 \%$ ). It seems, thus, that, in general, many PBOs relied on a few revenue sources.

Taken together, these results show that public funding, used in 2015 by over $90 \%$ of PBOs, accounted for almost $40 \%$ of the revenues of both sports clubs and other PBOs. The two groups, however, differed in terms of sources from 
which they obtained public funds. For sports clubs, the key role could be attributed to local self-government units, a consequence of the model of financing sports in Poland. Nine out of ten sports clubs received local self-government subsidies, which accounted for an average of $35 \%$ of the revenues all $\mathrm{PBO}$ sports clubs received in 2015. All other forms of public support - such as subsidies from the state budget, earmarked funds, and European funds - were used by no more than every tenth club, a smaller share than that for other PBOs. These revenue streams were, thus, less important in the revenue structure of sports clubs than of that in the rest of the non-profit sector. A separate category is donations of $1 \%$ of personal income tax, used only slightly less often by sports clubs than by other PBOs, but being much less significant in their total revenues.

\section{Discussion}

Like Polish sports clubs, Czech ones also base on self-government funds, which account for 35\% of their total revenues (Caslavova \& Berka, 2005, pp. 204-213). In some other countries and regions, however, public funding is less important, as in Canada and Spain (about a 7\% share), Flanders (Belgium) (below 9\%), and Germany (10\%) (Breuer et al., 2015, pp. 187-208; Enjolras, 2002, pp. 352-376; Lasby \& Sperling, 2007, pp. 49-50; Vos et al., 2013, pp. 55-71). Spanish sports clubs are atypical, with commercial sources dominating the revenue structure (Enjolras, 2002, pp. 352-376). The main revenue sources of German clubs are membership fees, donations, and subsidies (Breuer et al., 2015, pp. 187-208). In Spain and Canada, almost 30\% and 20\% of revenues, respectively, come from private sources (Lasby \& Sperling, 2007, pp. 49-50). In Poland, private sources account for less than one-fourth of all revenues of sports clubs.

Earlier research has indicated that many sports clubs rely on only a few particular revenue sources (Wicker et al., 2013, pp. 119-136), but, according to Chang \& Tuckman (1994, pp. 273-290), sports clubs more diversify their revenue structures than other NGOs. In Poland, a greater proportion of large sports clubs than that of other PBOs uses public funding, especially local self-government subsidies. Membership fees make another difference: A greater proportion of sports clubs charge membership fees. What is more, Polish sports clubs make profits from business activities (including sponsoring) more often than do other public benefit organizations, but they exploit the possibilities of paid public benefit activities less often. This agrees with the findings of Massarsky \& Beinhacker (2002, p. 3) that the area of activity of a non-profit organization affects its possibilities of undertaking business activities.

According to Vocasport's typology (Camy et al., 2004, pp. 54-61), the solutions adopted in Poland for financing sports belong to a bureaucratic configuration. Most commonly used in Europe, it assumes that public authorities play an active role in regulating the sports system. The other configurations are a missionary one (in which clubs have large autonomy in decision-making), an entre- 
preneurial one (in which private stakeholders prevail), and a social one (which assumes intense cooperation between private, public, and non-governmental entities). Henry (2009, pp. 41-52) combined this idea with management technique, an approach Vos et al. (2013, pp. 55-71) compared the revenues of German clubs (operating under the missionary configuration) and Flemish ones (operating under the social configuration). Based on membership fees, German clubs were, to a small extent, dependent on state support. Flemish clubs depended more on subsidies - but, unlike in Poland, sports policy in Flanders is highly decentralized. In Poland, the centralization of sports policy takes place at the level of public planning determined by the government's sport development strategy, but local self-governments are responsible for subsidizing amateur sports. Nevertheless, public funding is a key revenue source of Polish sports clubs, accounting for almost $40 \%$ of their revenues. It is thus clear that an adopted solution for financing sports affects sports clubs' revenue structure and sources. Another confirmation comes from the Czech Republic: Like Poland, it uses the bureaucratic configuration, and Czech sports clubs' financing is dominated by external sources - among which public funding, however, represents a much smaller share than that in Poland (25\% of the revenues) (Caslavova \& Berka, 2005, pp. 204-213).

\section{Conclusions}

To the best of the author's knowledge, this is the first work to compare the revenue structure of sports clubs with that of other PBOs. In fact, such research has been scarce also for other countries (in the context of NGOs) - thus, the study contributes to ongoing global research on financing sports clubs. The results reveal a contrasting picture of the revenue structures of sports clubs and other $\mathrm{PBOs}$ in Poland. Sports clubs more often than other PBOs receive subsidies from local self-government units, collect membership fees, and receive non-financial income. So, the important role subsidies play in sports clubs' revenue structure - a specific situation for Poland - results from the system of sports financing adopted in Poland. Membership fees, on the other hand, are typical of sports clubs worldwide: Accounting for only a small share of revenues of other PBOs, they do play an important role in sports clubs' revenue structure. Clubs use other revenue sources than the above-mentioned ones less frequently than do other PBOs, but they exploit public funding much more.

It shows government authorities how the organizational solutions adopted in Poland, a country following a bureaucratic model of sports financing, imply the revenues structure and sources of non-profit sport clubs. On this basis, it can be assumed that cross-country benchmarking is limited by contextual barriers. Therefore, when adopting a solution from abroad, the organizational patterns should be taken into account. As from the financial point of view SCs are different from other PBOs, policy makers should conduct supporting program 
dedicated solely to sports organizations instead of treating them like typical representatives of the third sector.

The main limitation of this study is that it dealt with only those sports clubs that have the status of a PBO. Considerably more work will need to be done to determine the factors influencing the differences in revenue structures that have been presented in this study. Moreover, future research should compare revenue sources of clubs with and without this status. It is also worth examining the dynamics of changes in the revenue structure of Polish clubs. Such knowledge might help check if a so-called 'crowding out effect' occurs in Polish sports clubs. This effect represents a situation in which public and private revenue sources are substitutable (e.g.: Dokko, 2009, pp. 57-75; Roberts, 1984, pp. 136-148; Warr, 1982, pp. 131-138). Some authors (Payne, 1998, pp. 323-345; Vesterlund, 2003, pp. 627-657), however, claim that the relationship is actually opposite: the increased level of public funding results in the increased level of revenues from non-public sources.

\section{References}

Achleitner, A.K., Spiess-Knafl, W., \& Volk, S. (2014). The financing structure of social enterprises: conflicts and implications. International Journal of Entrepreneurial Venturing, 6(1). doi:10.1504/ijev.2014.059404.

Adamiak, P., Charycka, B., \& Gumkowska, M. (2016). Kondycja sektora organizacji pozarzadowych w Polsce 2015: raport z badań. Retrieved 03.06.2018 from https://nck.pl.

Barget, E., \& Chavinier-Rela, S. (2017). The analysis of amateur sports clubs funding: a European perspective. Athens Journal of Sports, 4(1). doi:10.30958/ ajspo.4.1.1.

Breuer, C., Feiler, S., \& Wicker, P. (2015). Sport clubs in Germany. In C. Breuer, R. Hoekman, S. Nagel, \& H. van der Werff (Eds.), Sport Clubs in Europe: a cross-national comparative perspective. Cham: Springer. doi:10.1007/978-3-319-17635-2_11.

Breuer, C., Feiler, S., Llopis-Goig, R., \& Elmose-Østerlund, K. (2017). Characteristics of European sports clubs: a comparison of the structure, management, voluntary work and social integration among sports clubs across ten European countries. Retrieved 03.06.2018 from https://www.sdu.dk.

Camy, J., Clijsen, L., Madella, A., \& Pilkington, A. (2004). Improving employment in the field of sport in Europe through vocational training. Vocational education and training in the field of sport in the European Union: situation, trends and outlook. Retrieved 03.06.2018 from http://eose.org.

Caslavova, E., \& Berka, P. (2005). The financial management of sport clubs in the Czech Republic. Kinesiology, 37(2).

Central Statistical Office. (2017). Physical education in the years 2015-2016. Retrieved 03.06.2018 from https://stat.gov.pl. 
Chang, C.F., \& Tuckman, H.P. (1994). Revenue diversification among non-profits. Voluntas, 5(3). doi:10.1007/BF02354036.

Cieśliński, W.B., \& Perechuda, I. (2015). Profit and non-profit sports clubs: financial and organizational comparison in Poland. International Journal of Social, Behavioral, Educational, Economic, Business and Industrial Engineering, 9(6).

Coates, D., Wicker, P., Feiler, S., \& Breuer, C. (2014). A bivariate probit examination of financial and volunteer problems of non-profit sport clubs. International Journal of Sport Finance, 9(3).

Cordery, C.J., Sim, D., \& Baskerville, R.F. (2013). Three models, one goal: assessing financial vulnerability in New Zealand amateur sports clubs. Sport Management Review, 16(2). doi:10.1016/j.smr.2012.08.002.

Dokko, J.K. (2009). Does the NEA crowd out private charitable contributions to the arts? National Tax Journal, 62(1). doi:10.17310/ntj.2009.1.03.

Enjolras, B. (2002). The commercialization of voluntary sport organizations in Norway. Nonprofit and Voluntary Sector Quarterly, 31(3). doi:10.1177/0899764002313003.

Fischer, R.L., Wilsker, A., \& Young, D.R. (2011). Exploring the revenue mix of nonprofit organizations: does it relate to publicness? Nonprofit and Voluntary Sector Quarterly, 40(4). doi:10.1177/0899764010363921.

Gumulka, G., Barr, C., Lasby, D., \& Brownlee, B. (2005). Understanding the capacity of sports and recreation organizations. Retrieved 03.06.2018 form http://sectorsource.ca.

Henry, I. (2009). European models of sport: governance, organisational change and sport policy in the EU. Hitotsubashi Journal of Arts and Sciences, 50(1).

Kearns, K. (2007). Income portfolios. In D.R. Young (Ed.), Financing nonprofits: putting theory into practice. Plymouth: AltaMira Press.

Lasby, D., \& Sperling, J. (2007). Understanding the capacity of Ontario sports and recreation organizations. Retrieved 03.06.2018 from http://sectorsource. ca.

Liżewski, S. (2013). Źródta finansowania organizacji pozarządowych: pozyskiwanie, gospodarowanie, rozliczanie. Warszawa: Wiedza i Praktyka.

Massarsky, C.W., \& Beinhacker, S.L. (2002). Enterprising nonprofits: revenue generation in the nonprofit sector. Retrieved 03.06.2018 form https://community-wealth.org.

Ministry of Family, Labor and Social Policy. (2018). The electronic database of financial and substantive reports of public benefit organizations. Retrieved 12.07.2019 form https://sprawozdaniaopp.niw.gov.pl.

Nagel, S. (2008). Goals of sports clubs. European Journal for Sport and Society, 5(2). doi:10.1080/16138171.2008.11687815.

Payne, A.A. (1998). Does the government crowd-out private donations? New evidence from a sample of non-profit firms. Journal of Public Economics, 69(3). doi:10.1016/S0047-2727(98)00005-X. 
Roberts, R.D. (1984). A positive model of private charity and public transfers. Journal of Political Economy, 92(1). doi:10.1086/261212.

Sotiriadou, P., \& Wicker, P. (2013). Community sports clubs' responses to institutional and resource dependence pressures for government grants. Annals of Leisure Research, 16(4). doi:10.1080/11745398.2013.853338.

Ustawa z dnia 24 kwietnia 2003 r. o działalności pożytku publicznego i o wolontariacie [Act of 24 April 2003 on Public Good Activity and Volunteering] (Dz.U. 2003 nr 96 poz. 873) (Poland).

Ustawa z dnia 25 czerwca 2010 r. o sporcie [Act of Sport] (Dz.U. $2010 \mathrm{nr} 127$ poz. 857) (Poland).

Vesterlund, L. (2003). The informational value of sequential fundraising. Journal of Public Economics, 87(3-4). doi:10.1016/s0047-2727(01)00187-6.

Vos, S., Wicker, P., Breuer, C., \& Scheerder, J. (2013). Sports policy systems in regulated Rhineland welfare states: similarities and differences in financial structures of sports clubs. International Journal of Sport Policy and Politics, 5(1). doi:10.1080/19406940.2012.657665.

Warr, P.G. (1982). Pareto optimal redistribution and private charity. Journal of Public Economics, 19(1). doi:10.1016/0047-2727(82)90056-1.

Wicker, P., \& Breuer, C. (2011). Scarcity of resources in German non-profit sport clubs. Sport Management Review, 14(2). doi:10.1016/j.smr.2010.09.001.

Wicker, P., Feiler, S., \& Breuer, C. (2013). Organizational mission and revenue diversification among non-profit sports clubs. International Journal of Financial Studies, 1(4). doi:10.3390/ijfs1040119.

Wicker, P., Longley, N., \& Breuer, C. (2015), Revenue volatility in German nonprofit sports clubs. Nonprofit and Voluntary Sector Quarterly, 44(1). doi:10.1177/0899764013499072.

\section{Acknowledgements}

Author contributions: author has given an approval to the final version of the article.

Funding: this research was undertaken as part of the Przedsiębiorczość w zarządzaniu sportem project and was fully funded by a grant (K/ZDS/008296).

Note: the results of this study were presented at 10th Conference of the European Sport Economics Association (August, 29-31 2018, Liverpool, United Kingdom). 


\section{Appendix}

\section{Table 1.}

\section{Classification of revenue sources of PBOs by type of activity}

\begin{tabular}{|c|c|c|}
\hline Activity & Description & Revenue sources \\
\hline $\begin{array}{l}\text { unpaid } \\
\text { activity }\end{array}$ & Activities for which an NGO is not paid. & $\begin{array}{l}\text { - membership fees, } \\
\text { - donations, } \\
\text { - bequests, } \\
\text { - legacies, } \\
\text { - grants, } \\
\text { - subsidies, } \\
\text { - income from public generosity. }\end{array}$ \\
\hline $\begin{array}{l}\text { paid } \\
\text { activity }\end{array}$ & $\begin{array}{l}\text { Activities for which an NGO is paid; included are activities } \\
\text { listed in the next column, except for sponsorship. }\end{array}$ & \multirow[b]{2}{*}{$\begin{array}{l}\text { - sale of manufactured goods, } \\
\text { - provision of services in the field of re- } \\
\text { habilitation of persons with disabilities } \\
\text { or occupational integration of people } \\
\text { at risk of social exclusion, } \\
\text { - sales of donations, } \\
\text { - sponsorship*. }\end{array}$} \\
\hline $\begin{array}{l}\text { business } \\
\text { activity }\end{array}$ & $\begin{array}{l}\text { A paid activity becomes a business activity if: } \\
\text { - a remuneration for the activity exceeds the operating } \\
\text { costs; or } \\
\text { - the average monthly salary of employers of the organ- } \\
\text { ization exceeds three times the average monthly salary } \\
\text { in the enterprise sector. }\end{array}$ & \\
\hline $\begin{array}{l}\text { other } \\
\text { activities }\end{array}$ & $\begin{array}{l}\text { Other activities, not listed in the Act on Public Good } \\
\text { Activity and Volunteering (2003). }\end{array}$ & $\begin{array}{l}\text { - income from property, capital invest- } \\
\text { ments, and endowment funds, } \\
\text { - compensatory damages, } \\
\text { - other sources: credits, loans. }\end{array}$ \\
\hline
\end{tabular}

Note:

* Sponsorship is a business activity and, thus, cannot be treated as a statutory paid activity (Liżewski, 2013, p. 43).

Source: Own elaboration based on the Act on Public Good Activity and Volunteering (2003) and Adamiak et al. (2016). 
Table 2.

Summary statistics for shares the analyzed sources had in the revenues of sports clubs (SCs) and other PBOs in 2015

\begin{tabular}{|c|c|c|c|c|c|c|c|c|}
\hline Specification & & $\mathrm{N}$ & $\begin{array}{l}\text { Mean } \\
\text { (in \%) }\end{array}$ & $\begin{array}{c}\text { Standard } \\
\text { deviation } \\
\text { (in \%) }\end{array}$ & $\begin{array}{l}\text { Coefficient } \\
\text { of variation } \\
\text { (in \%) }\end{array}$ & $\begin{array}{l}\text { Median } \\
\text { (in \%) }\end{array}$ & Skewness & $\begin{array}{l}\text { Maximum } \\
\quad \text { (in \%) }\end{array}$ \\
\hline \multirow{2}{*}{ unpaid activity } & SCs & 679 & 55 & 43 & 77 & 64 & -0.17 & 100 \\
\hline & PBOs & 6816 & 64 & 39 & 61 & 85 & -0.60 & 100 \\
\hline \multirow{2}{*}{ paid activity } & SCs & 679 & 10 & 23 & 235 & 0 & 2.58 & 100 \\
\hline & PBOs & 6816 & 11 & 24 & 221 & 0 & 2.41 & 100 \\
\hline \multirow{2}{*}{ business activity } & SCs & 679 & 7 & 20 & 267 & 0 & 3.03 & 100 \\
\hline & PBOs & 6816 & 4 & 14 & 401 & 0 & 4.85 & 100 \\
\hline \multirow{2}{*}{ other activities } & SCs & 679 & 27 & 37 & 137 & 1 & 0.97 & 100 \\
\hline & $\mathrm{PBOs}$ & 6816 & 21 & 34 & 160 & 1 & 1.42 & 100 \\
\hline \multirow{2}{*}{ public sources } & SCs & 365 & 41 & 28 & 71 & 38 & 0.23 & 100 \\
\hline & PBOs & 3879 & 49 & 36 & 87 & 37 & 0.24 & 100 \\
\hline \multirow{2}{*}{ European Union subsidies } & SCs & 365 & 1 & 5 & 841 & 0 & 11.84 & 84 \\
\hline & PBOs & 3879 & 4 & 15 & 358 & 0 & 4.16 & 99 \\
\hline \multirow{2}{*}{$\begin{array}{l}\text { donations of } 1 \% \text { personal } \\
\text { income tax }\end{array}$} & SCs & 365 & 2 & 5 & 202 & 1 & 8.09 & 65 \\
\hline & $\mathrm{PBOs}$ & 3879 & 8 & 17 & 199 & 2 & 3.11 & 100 \\
\hline \multirow{2}{*}{ governmental subsidies } & SCs & 365 & 2 & 9 & 438 & 0 & 5.61 & 77 \\
\hline & $\mathrm{PBOs}$ & 3879 & 9 & 22 & 226 & 0 & 2.49 & 100 \\
\hline \multirow{2}{*}{ self-government subsidiaries } & SCs & 365 & 35 & 28 & 79 & 34 & 0.37 & 100 \\
\hline & $\mathrm{PBOs}$ & 3879 & 21 & 29 & 141 & 5 & 1.38 & 100 \\
\hline \multirow{2}{*}{ target funds } & SCs & 365 & 1 & 6 & 629 & 0 & 7.14 & 59 \\
\hline & $\mathrm{PBOs}$ & 3879 & 7 & 19 & 284 & 0 & 3.17 & 99 \\
\hline \multirow{2}{*}{ private sources } & SCs & 365 & 23 & 24 & 104 & 16 & 1.31 & 100 \\
\hline & PBOs & 3879 & 21 & 27 & 129 & 9 & 1.50 & 100 \\
\hline \multirow{2}{*}{ membership fees } & SCs & 365 & 9 & 16 & 180 & 1 & 2.74 & 96 \\
\hline & PBOs & 3879 & 3 & 10 & 373 & 0 & 5.80 & 100 \\
\hline \multirow{2}{*}{ donations from individuals } & $\mathrm{SCs}$ & 365 & 7 & 14 & 193 & 1 & 3.16 & 98 \\
\hline & PBOs & 3879 & 9 & 18 & 193 & 2 & 3.00 & 100 \\
\hline \multirow{2}{*}{ donations from firms } & SCs & 365 & 4 & 12 & 285 & 0 & 4.39 & 91 \\
\hline & $\mathrm{PBOs}$ & 3879 & 7 & 17 & 243 & 0 & 3.40 & 100 \\
\hline \multirow{2}{*}{ public generosity } & SCs & 365 & $<0$ & 1 & 951 & 0 & 11.32 & 8 \\
\hline & $\mathrm{PBOs}$ & 3879 & $<1$ & 6 & 508 & 0 & 8.60 & 100 \\
\hline \multirow{2}{*}{ inheritances } & SCs & 365 & 2 & 11 & 464 & 0 & 5.91 & 100 \\
\hline & PBOs & 3879 & 1 & 7 & 686 & 0 & 9.31 & 98 \\
\hline \multirow{2}{*}{ other sources } & SCs & 365 & 36 & 30 & 85 & 31 & 0.56 & 100 \\
\hline & PBOs & 3879 & 29 & 32 & 109 & 16 & 0.90 & 100 \\
\hline
\end{tabular}

Source: Own elaboration based on Ministry of Family, Labor and Social Policy of Poland (2018). 


\section{Chart 1.}

The shares of sports clubs and other PBOs in generating revenues in 2015 from the analyzed sources (in \%)

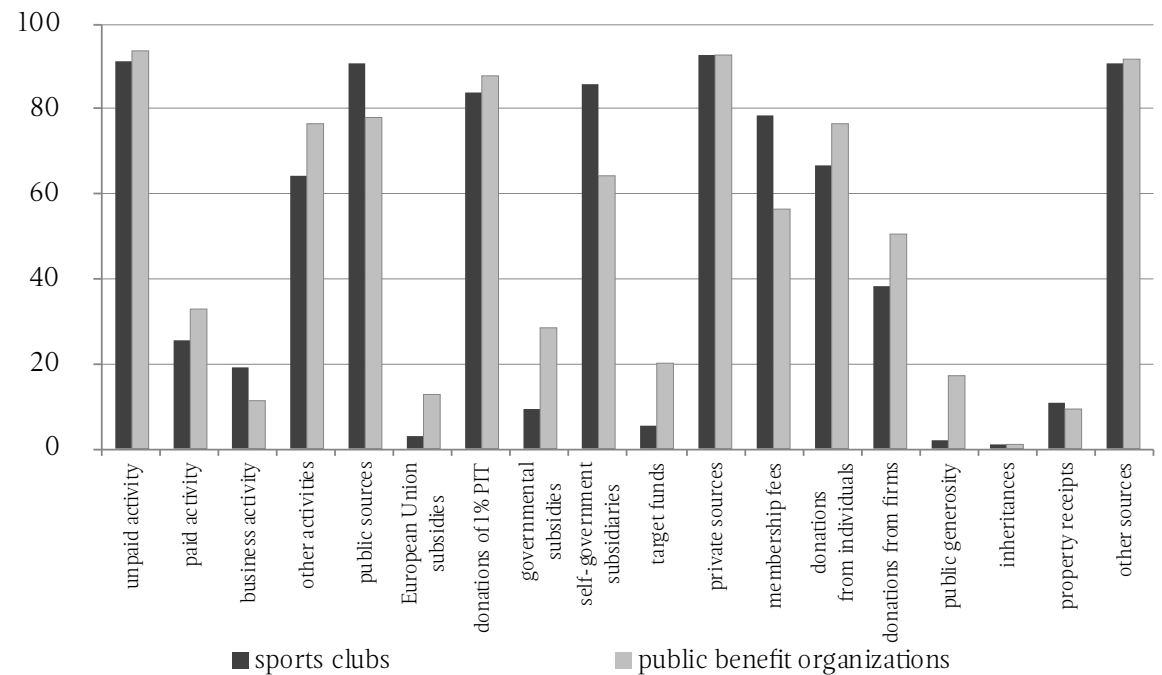

Source: Own elaboration based on Ministry of Family, Labor and Social Policy of Poland (2018). 